\title{
Understanding Learning Styles, Attitudes and Intentions in Using e-Learning System: Evidence from Brunei
}

\author{
Afzaal H. Seyal ${ }^{1, *}$ \& Mohd Noah A. Rahman ${ }^{1}$ \\ ${ }^{1}$ School of Computing \& Informatics, Institut Teknologi Brunei, Brunei Darussalam \\ *Correspondence: School of Computing \& Informatics, Institut Teknologi Brunei, Gadong BE 1410, Brunei \\ Darussalam. Tel: 673-246-1020.E-mail: afzaal.seyal@itb.edu.bn
}

Received: April 15, 2015

Accepted: April 30, $2015 \quad$ Online Published: May 12, 2015

doi:10.5430/wje.v5n3p61

URL: http://dx.doi.org/10.5430/wje.v5n3p61

\begin{abstract}
This study investigates the students' learning style, their attitudes about educational technologies in general and e-learning management system (e-LMS) in particular and their behavioral intentions to use the e-learning platform in a single institution of higher learning in Brunei Darussalam. In this study, a survey, using the VARK Questionnaire as a tool to describe the learning styles of students, was conducted among 120 students. The data analyzed through SPSS confirmed that there existed a relationship between students' learning style (Kinesthic-doing), their attitude towards e-LMS and their intention to adopt university's e-learning platform "Ask-n-Learn". Recommendations were made in order to enhance pedagogy in the context of e-learning.
\end{abstract}

Keywords: VARK learning style; e-learning system; behavioral intentions; institutions of higher learning

\section{Introduction}

For over thirty years, the research on learning styles was given importance in pedagogy research. Howles (2007) reported that research on learning styles emerged in the early 1960's. Over 4500 articles have been written about learning styles in professional publications and over 26,000 Websites are available for measuring and addressing learning styles. There are over thirty commonly used learning styles that are grouped into cognitive, learning and personality and aptitude-based however, not all have been empirically validated (www.howlesassociates.com). Bart, (2009) reported more than 650 books published in the USA and Canada alone and suggested, that a Google search on learning styles will yield over 2,000,000 websites. These statistics indicate the importance of learning styles on the teaching/learning paradigm.

The implication between understanding the learners' learning style to encourage and facilitating the complex learning process remained as one of the most debatable topics in the recent past. Majority of academic institutions of higher learning strive to develop the instructional design theory in order to promote more a conducive learning environments for learners. The three main schools of thought such as Behaviorism, Cognitivism and Constructivism (as quoted by Peter et al., 2009) have a large impact in learning and instructional design. The behaviorism approach (Skinner, 1974; Watson, 1930) is one that sees the mind as a "black box" that responds to stimulus. The cognitivism approach deals with the information processing habits of the learners and that 'black box' should be opened and understood. In the constructivism approach, (Dewey 1966; Montessori 1914; Piaget 1973) the learners interact with the environment and then construct their own knowledge based on that interaction.

The diversity in teaching and learning styles has gained more attention in educational research as many studies described the preferred learning styles that would ideally match the former (Reid 1987; Zhenhui 2001; Too 2009). These studies have pointed out that it is vital for instructors or teachers to have awareness of their learners' needs, capacities, potentials and learning styles preferences in order to have effective classroom teaching and learning. Yilmaz-Soylu and Akkoyunlu (2002) stated that though all human beings had common bio-psychological and social characteristics in learning process, individual preferences on ascribing meaning and acquiring information may vary. The information which becomes the subjective life of an individual may have individual-specific differences in his way of learning and remembering. Therefore, it is important to study the students' learning style to understand the teaching/learning process. 
In addition, student learning in tertiary institutions has undergone a paradigm shift with the availability and use of information and communication technologies (ICTs) (Bassey et al., 2007). Pedagogy coupled with ICT-based deliverables have undergone a transformation from traditional approach of teacher-oriented/teacher-centered to modern method where ICT plays a significant role, thus facilitating the learners to learn with ease and comfort at their own pace. This change in teaching learning with the help of ICT has brought a revolution in students 'learning with a new wave of e-learning (Bassey et al., 2007). E-Learning is defined as learning that is enabled by the applications of the Internet and digital technologies such as Web pages, video conferencing system and CD-ROMs (Urdan and Weggen, 2003). Many higher education institutions adopt Web-based learning systems for their e-Learning courses called Learning Management System (LMS). However, the success of this at individual institutions depends on several factors. There is limited empirical evidence as to the factors that influence the adoption of Web-based learning systems (Abbad and Morris, 2009). The benefits of LMS coupled with the developing and operating costs, the organizational adoption of the LMS in many tertiary institutions are at infant stage. This is mainly due to the successful implementation of system that requires a solid understanding of user acceptance processes and ways of persuading users (students) to utilize these technologies (Abbad and Morris, 2009). To strengthen the process of implementation, understanding and measuring users' attitude play an important role in analyzing user behavior because it is known that there is a strong connection between attitude and behavior (Bertea, 2009). Within the context of e-Learning a favorable attitude shows greater probabilities that learner will accept the new system (ibid).

There are several factors such as organizational, environmental, technological and personal that develops the right attitude towards accepting the new learning system. Factors such as patience, self-discipline and confidence, ease of software use, peer support, good technical skills and abilities regarding time management impact on students' attitude towards e-Learning. Learners are both emotional and intellectual; and emotions have effects on learners' perception and what they do (Ndume et al., 2008).

In regard to the impact of learning style and attitude on adoption of e-Learning management system, there have been few studies that focused on factors such as analyzing individual characteristic, and learning styles in implementing LMS among tertiary institutes. However, some studies evaluated the role of demographical characteristics in the implementation of LMS. There exists a research gap that needs to be filled by studies using students' individual and emotional perspective. Motivated by these assumptions a study was conducted in December 2014 in one of the technical institutions of higher learning in Brunei Darussalam with the following objectives:

1. To understand the most common learning style of the respondents in the faculty of computing \& business.

2. To understand the role of the students' learning style and attitudes towards educational technologies in general and toward e-Learning in particular in acceptance of e-LMS.

\section{Review of Literature}

Literature in general is full of studies that focused on the relative importance of learning styles in improving the teaching/learning at higher institutions. Some have focused on enhancing the delivery of teaching/learning through e-Learning.

Learning Style: Learning style is defined as the "composite of characteristics; cognitive, affective and physiological characters that serve as relatively stable indicators on how a learner perceives, interacts with and responds to his learning environments" (Keefe, 1979). All students, regardless of culture, have a preferred style of learning. Marsh (2004) cites Dunn's comment that learning styles are as "individual as a signature" (p.167). However, it is possible to broadly categorize learning styles. Fleming and Mills (1992) suggested four categories that reflect the experiences of their students. The learning styles were reported in the literature categorized as sensory like VARK model (Fleming and Mills, 1992) and cyclical such as Kolb's Learning Styles Inventory (KLSI) (Kolb, 1984), Honey and Mumford (1982) learning style theories, Felder-Silverman Index of Learning Style (LSI) model (Felder \& Silver, 1988). Another model is the Myers and Briggs Type Indicator (MBTI) (Myers, 1962) that was based on personality types. However, Allert (2004) stated that there were two dominant learning style assessment tools used in science and engineering education. For Kolb's KLSI and Felder-Silverman's (LSI), both these models measured four different dimensions of an individual's learning style. In educational research both KLSI and VARK learning styles are used and have their strengths and weaknesses. Therefore we have selected for this study the VARK model (Fleming \& Mills, 1992) simply because that instrument was very simple and did not ask on lengthy questions like LSI that had 44 questions, i.e. 11 for each of the four dimensions. VARK took only five minutes to fill-in the desired response. Loo (1999) also suggested that this instrument remained effective to study students' learning style among tertiary 
students.

According to Sampson and Karagiannidis (2002) learning styles have been a controversial issue for several decades and there is still little agreement about what learning styles really are. Similarly, Ayesha et al., (2011) studied learning style preferences by using VARK to study the preclinical medical students in one of the Saudi Arabian medical colleges. Their results show that $73 \%$ of the respondents have multiple learning styles. In addition, Coffield et al. (2004) showed a detailed evaluation of common learning style and categorized them according to their theoretical importance. In particular, they identified the five families of learning styles:

1. Constitutionally-based learning style that includes VAKT (visual, auditory, kinesthetic and tactile), Dunn and Dunn (1978) and VARK (Fleming \& Mills, 1992).

2. Cognitive structure including pattern of ability, e.g. multiple intelligences (Gardner, 1993).

3. A relatively stable personality type, e. g. Myers and Briggs type (Myers et al. 1998).

4. Flexibly stable learning preferences, e.g. Kolb learning style (1985).

5. Learning approaches, strategies, orientations and conceptions of learning, e.g., Vermunt (1998).

Learning styles of the students were evaluated and VARK was selected for e-LMS (Ask and Learn) learner profile because it was the most concise tool and provided more relevant questions (Peter et al. 2009). VARK was also found to be useful in clearly mapping out the learning style to the types of e-learning material (ibid).

Table 1. Various Dimensions of VARK

\begin{tabular}{|c|c|c|}
\hline VARK Learning styles & $\begin{array}{l}\text { Fleming's recommendation of } \\
\text { study e-Learning }\end{array}$ & $\begin{array}{l}\text { e-Leaning "Ask and } \\
\text { learning" (How use) }\end{array}$ \\
\hline $\mathrm{V}$ (visual) & $\begin{array}{l}\text { Pictures, videos, posters, slides, } \\
\text { flowchart, graph and diagram }\end{array}$ & Video, PP slide $\mathrm{n}$ show \\
\hline A (audio) & $\begin{array}{l}\text { Discussion topics and ideas, } \\
\text { remembering stories and jokes }\end{array}$ & $\begin{array}{l}\text { PP slides with audio } \\
\text { Podcast }\end{array}$ \\
\hline $\mathrm{R}$ (reading) & $\begin{array}{l}\text { List, headings, dictionaries, } \\
\text { definitions, textbook and manual }\end{array}$ & $\begin{array}{l}\text { PP slides hands-on, Text } \\
\text { documented, Published } \\
\text { resources }\end{array}$ \\
\hline K (kinesthetic-doing) & $\begin{array}{l}\text { Interested in doing, practical real } \\
\text { and relevant }\end{array}$ & $\begin{array}{l}\text { Design assignment, } \\
\text { practice exercises }\end{array}$ \\
\hline Multimodal & \multicolumn{2}{|c|}{ Mix of the above learning styles and learning objectives } \\
\hline
\end{tabular}

Attitudes and e-Learning: Attitude refers to the degree of a student's general feeling of favorableness or unfavorableness about performing behavior. Attitude towards a behavior actually stems from a set of salient beliefs (known as behavioral beliefs), i.e., performing the behavior will lead to certain consequences (Randall, 1989). Consequences may be either positive or negative, and may affect students or other parties. Therefore, the more positive the perceived consequence of behavior, the more favorable is the attitude towards the behavior. In context to e-learning, a student may believe that the using an e-learning may lead to increased knowledge, and competitive edge among others. In other words, if a student thinks that there is more to be gained than lost by using e-learning based learning management system, he or she is more likely to use it. Many studies have shown the significant affect of attitude towards intention and use of the information systems (Davis et al. 1989; Mathieson, 1991; Taylor and Todd, 1995; Lu et al. 2003; Shih and Fang, 2004; Ramayah et al. 2004 and Ramayah and Suki, 2006; Adewole-Odeshi, 2014; Wong, 2012 and Brumini et al., 2014).

Wernet et al. (2000) surveyed students who used WebCT in a social work course; found that all of the respondents consider that the online course materials are beneficial to their overall learning experience. Sanders and Morrison-Shelter (2002) examined student attitudes with regards to the Web-enabled learning components in a general biology course for undergraduate. The results show a positive effect on student learning, problem-solving skills, and critical thinking skills. Paris, (2004) examined the cognitive, effective and behavioural attitudes of fifty-two year ten students from a public schools in Australia to further assess specific online e-learning (OWAL). The results indicate students responded better towards OWAL, however gender based difference in attitudes was noticed. Positive correlation was noticed among the Internet users and OWAL attitudes.

Downey et al. (2005) investigated the relationship between the national culture and the usability of an e-learning 
system and cited the relationship between national culture and the e-learning usability. Selim, (2005) studied 538 students to specify eight e-learning critical success factors as perceived by the students that included; students' motivation, attitudes and technical competency, instructors' attitudes about students' e-learning, instructors' teaching style and university support for e-learning activities as top five factors out of the eight. Cheng, (2006) studied 180 students' acceptance towards e-learning in technical college in Taiwan and identified the positive attitudes of the students about e-learning. Results indicated that the demographical variables such as gender, computer skills and school system remained insignificant. However, the experience of applying e-learning for business courses played a key factor in the level of users of e-learning.

Al-Khashab, (2007) studied 276 respondents to find about the Kuwait society's attitudes toward e-learning. The results show that there is a significant difference in the attitudes towards e-learning based on educational level. They also found that Kuwaiti students generally have good attitudes towards e-learning. Similarly, another study conducted by Al-Doub et al. (2008) in Kuwait College of Business Studies indicated that students were keen to use e-learning and there are some significant differences between the male and female students in their attitudes to use of e-learning materials. Buzzetto-More, (2008) studied the students' perception of various e-learning components by designing a Web-based Course Management System. The results indicate that students find course Websites to be helpful resources that enhances the understanding of course content. In addition, students responded favourably towards online submission of assignments. Safavi (2008) in his Iranian-based study described e-learning model and guidelines for developing countries intending to adopt the e-learning system.

Seyal, (2010) investigated 220 students from the faculty of Business and Computing in Brunei Darussalam to identify the factors that are responsible for establishing the e-learning intentions by using Theory of Reasoned Action (TRA) (Fishbein \& Ajzen, 1975) as a reference framework to understand e-learning intentions. The results show that majority of the students has a positive attitude towards e-learning with a mean of 3.67. The results further suggest that students' attitude toward e-learning and subjective norms, the two important underlying constructs of TRA, are significantly related to their intention to use e-learning systems.

Brown et al., (2009) studied the learning style preference of health science students to predict their attitudes to e-learning. They used Index of Learning Style (ILS) and Online Learning Environment Survey (OLES). The results indicate that student Active-Reflective and Sensing-Intuitive learning style were the most frequent predictors of health science students' attitude towards e-learning.

In conclusion, it is evident that researchers have studied the e-learning usage and organizational adoption and that e-learning is becoming a standard for today's education, as it opens the door to learning focusing on the individuals priorities and learning skills. Similarly, the relationship between learning styles and attitudes to e-learning has received attentions in the empirical literature (Effken \& Doyle, 2001; Dunn \& Griggs, 2003). According to Grasha and Yangarber-Hicks, (2000), students' performance, when faced with technology, is very much tied to their particular learning style preferences.

The Learning Style \& E-Learning Model: Researchers have studied the effect, impact and influence of learning styles of learners in e-Learning environments. The studies were not confined to a particular learning style rather to a variety of learning styles that were used by various researchers. Monochehr (2006) studied the influence of learning styles on learners in e-Learning environment in Qatar. The results indicated that students with Assimilator learning style (learn through lecture, papers and analogies) and the Convergers learning style (learn best through field work, lab and observations) achieved a better result with e-Learning (Web-based) method. Peng and Ming-Jen (2010) investigated the students' satisfaction with e-learning system with two moderating effect contingent variables, student job status and learning style and found crucial for improving e-learning system satisfaction. In addition, Cheng and Wong (2014) studied the student learning style by using Index of Learning Style (ILS) in University of Hong Kong and the acceptance of using second life (SL) for learning. They concluded that visual learners are more commonly observed style among respondents. However, active learners were found more likely to accept the educational use of SL.

Peter et al. (2009) identified a number of adaptive e-learning system research projects that have used learning styles to adapt their learning environment to the user. This was supported by a number of studies that used learning styles with e-learning projects, such as the following:

- ACE (Spech \& Opperman, 1998).

- Carmona (SIGUE, 2002 and Bajraktarevic, et al. 2003).

- Camelon (Laroussi, and Benahmed, 1998) used the Felder Silverman's index of learning style. 
- INSPIRE (De-Bra, Brusilovshy and Kobsa, 2001) and SMILE used Honey and Mumford style.

- iWeaver (Wolf, 2003) uses the Dunn and Dunn model

- APeLs (Conlan, 2004) and iLearn (Peter et al., 2009).

The main purpose of previous research on e-learning was to adopt the content presentation to the learners. Brusilovsky and Millan (2007) state that there are no proven recipes for the application of learning styles within adaptive e-learning system and they also state that it is still unclear which aspects of learning style are worth modeling and what can be done differently for users with different style. Peter et al. (2009) research show an evidence to incorporate VARK learning style and e-learning platform i-Learn and demonstrated as how it would be used to provide the relevant material for the learners based on their learning types. The research also addresses the issues with personalization of common learning management system and provides learners with a personalized learning experience. The understanding of learning styles can be used to devise effective e-learning implementation strategies and platform but it is also useful in implementing better teaching and learning strategies (Coffield et al. 2004). Learning styles have also been shown to have an impact on the effectiveness of online learning (Allert, 2003; Carver et al., 1999).

\section{Methodology}

\subsection{Design of Instrument}

From the review of the literature and on the basis of the study design, the questionnaire was adapted after Fleming and Mills (1992). The multidimensional instrument was developed in two parts to capture the information. Part 1 contained demographic data and includes and information about students learning skills, behavioral intentions, and problems associated with not using e-LMS consisting of questions with nominal and ordinal measurements. Part 2 captured information about learners' attitude towards educational technologies and their attitude on e-LMS. A set of 20 -items were initially selected from the literature to measures the students' attitude toward computer (Selwyn, 1997) and were modified to cater for the need of e-learning. Part 3 captured the information on sixteen questions about the VARK learning styles. Each statement are further divided into four options from "a" to "d" covering all four learning styles. Table 2 provides details of the sources of constructs and the number of items used in this study.

\subsection{Sampling \& Data Collection}

Convenience sampling was conducted with the selection of students randomly within two faculties. The questionnaire was distributed to one hundred and sixty-five students randomly for computing as well as business faculties. One hundred and twenty sets of questionnaire were returned with the response rate of $73 \%$. The study was conducted in Dec 2014. The basic statistics and reliability coefficient are indicated in Table 2.

\subsection{Limitation of the Study}

Like all other studies, the study is not free from its weaknesses. The sample size used for this study is subject of standard error. Secondly, all data measuring the students' learning style and attitudes derived from self-reports; it is likely that common method variance influences the results and the data collected at different times or through different methodologies could produce different results. Finally, any attempt to generalize the results based upon single institution study should be used with caution.

\subsection{Validity and Reliability}

In order to assess the validity and reliability, tests were performed in this study. To get the reliability of the questionnaire, the coefficient of Cronbach's alpha (1951) was taken into account. Minimum Cronbach's alpha value of above 0.70 indicates reliability of the instrument (Nunnally, 1978). During the initial screening of conducting reliability tests, the items were dropped because of low corrected-item total correlation which was less than .40, the cut-off value suggested (Hair et al. 1998). The remaining items were applied where the factor analysis was subjected to principal component analysis using varimax rotation. In addition, we applied the criteria of Kaiser-Normalization as techniques of rotation to examine both the individual items and the relationship among them (Hair et al. 1998). All the items that were loaded on which had more than one factor at cut-off value of .40 were eliminated from the constructs (The result of the factor analysis is not attached to avoid the unnecessary length of the paper). In addition, two types of validity were assessed to validate: convergent and discriminant validities. Churchill, (1979) has suggested that convergent and discriminant validities should be examined for construct validity. Therefore, we assessed convergent validity by examining composite reliability (CR) and average variance extracted (AVE) from the three constructs (Hair et al. 1998). 
CR is calculated by squaring the sum of loadings, and then dividing it by the sum of squared loadings, plus the sun of the measurement error whereas, the AVE is measured with the variance captured by the indicators relative to measurement error. Table 2 provides the quality control statistics with internal consistency average variance explained (AVE) and CR values. The CR values of both the constructs were between the suggested minimum of 0.70 (Hair et al., 1998). Table 2 also represents the variance. The average variance extracted above 0.50 suggests a further evidence of convergent validity (Fornell and Larcker, 1981) These AVE values could also be used to assess discriminant validity which occurs when the AVE exceed the square pair wise correlation between the construct (Espinoza, 1999).

Table 2. Quality Control Statistics

\begin{tabular}{llllllll}
\hline Constructs & $\begin{array}{l}\text { No of } \\
\text { original } \\
\text { items }\end{array}$ & $\begin{array}{l}\text { No of } \\
\text { items } \\
\text { retained }\end{array}$ & $\begin{array}{l}\text { Alpha } \\
\text { value (.60 } \\
\text { and } \\
\text { above) }\end{array}$ & $\begin{array}{l}\text { Mean } \\
\text { Variance } \\
\text { explained } \\
\text { (AVE) } \\
<.50\end{array}$ & CR & Source \\
\hline $\begin{array}{l}\text { Attitude on Educational } \\
\begin{array}{l}\text { Technologies } \\
\text { Attitude-E-Learning }\end{array}\end{array}$ & 9 & 9 & .88 & 3.98 & .60 & .78 & Selwyn, (1997) \\
$\begin{array}{l}\text { Management System } \\
\text { (e-LMS) }\end{array}$ & 9 & $4 *$ & .83 & 3.70 & .68 & .80 & Selwyn, (1997) \\
$\begin{array}{l}\text { Behavioral intentions } \\
\text { Total }\end{array}$ & 2 & 2 & .87 & 3.35 & .70 & .81 & Davis et al. (1989) \\
\hline
\end{tabular}

(* items dropped because of lowest corrected-item correlation less than .40)

\section{Data Analysis and Results}

\subsection{Background Profile}

The background of the participating students is summarized in Table 3. There were more female respondents because Bruneian tertiary school enrollment has more female than the male students (Bruneian Year Book, 2012). A good number of students (40\%) students were in the age group 21-23 years. The majority of the students $(90 \%)$ are from the Degree area and majority ( $88 \%)$ is from the computing program area.

Table 3. Demographical Data

\begin{tabular}{llc}
\hline Variable & Description & Percentage \\
\hline Gender & Male & 40 \\
& Female & 60 \\
Age & Between 18-20 & 26 \\
& Between 21-23 & 40 \\
& Between 24-26 & 12 \\
Type of Program & Above 26 & 22 \\
& Higher National Diploma & 10 \\
Year of studies & Degree & 90 \\
& $1^{\text {st }}$ year & 68 \\
Faculty & $2^{\text {nd }}$ year & 10 \\
& $3^{\text {rd }}$ year & 22 \\
Intentions to use & Computing & 88 \\
& Business & 12 \\
\hline
\end{tabular}


Table 3. Demographical Data(Continued)

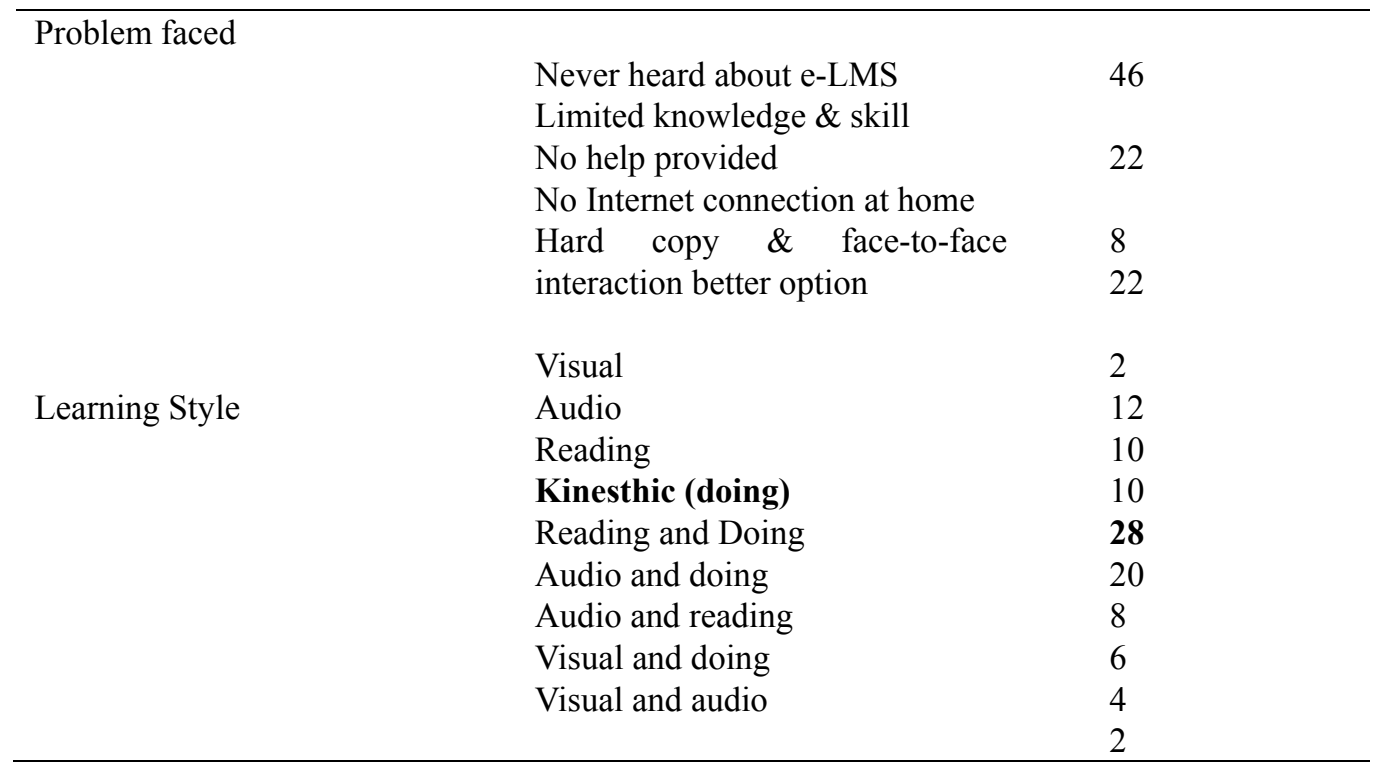

\subsection{Regression Analysis}

The relationship of students' attitudes and subjective norms, with the dependent variable (which is how strongly a student had intention to use a learning management system), was investigated using multiple regression analysis. Multicollinearity was examined by analyzing each independent variable's variance inflation factor (VIF) (Hair et.al.1998). Multicollinearity problem did not appear to exist, as VIF value of each variable was much less than 10. The results (as presented in Table 4) explain 24\% variance in the dependent variable. One of the independent variables e.g. students' attitude, towards e-LMS, was found to have significant standardized regression coefficients, and is related to students' intention to use e-learning.

Table 4. Regression Analysis

\begin{tabular}{lcclll}
\hline Constructs & Beta & t-value & Sig & VIF & Result \\
\hline Attitude-ET & -.125 & -1.34 & .175 & 1.32 & Not-significant \\
Attitude-e-LMS & .331 & 3.27 & $.011^{*}$ & 1.28 & Significant \\
Learning style & .074 & 2.38 & $.024^{*}$ & 1.26 & Significant \\
\hline
\end{tabular}

$R^{2}=24 \%, F=2.85, p<0.05$ (Dependent variable: Behavioural intentions)

\section{Discussion}

This study identified students' learning style and attitude towards implementation of e-LMS. The most commonly used style is kinesthetic one that the students believe on doing $(28 \%)$. Whereas Reading +Doing (20\%) remains second most common learners' style. The results are in contrast with the other studies that studied the VARK learning style among medical students and found that $5.5 \%$ are visual; $11.6 \%$ are aural, $8.2 \%$ Kinesthetic and $2.1 \%$ are $\mathrm{read} / \mathrm{write}$ and whereas, $73 \%$ have multiple learning styles (Ayesha et al., 2011). Similarly the results are in contrast with another study in 2008 which has estimated that about $5 \%$ of the world population has Kinesthetic/Tactile learning style(Note 1). The results of learning style provide useful information for improving quality of the LMS. Kinesthetic learners tend to be touchers and feelers. They process information through the sense of touch, such as by feeling shapes and textures. While they make a lot of notes while attending lectures often they will not refer to the notes again. Experiential and hands-on learning activities are usually the best method for these types of learners, such as lab work, role playing and making model. It is suggested that computer can be useful with this learning style, particularly for reinforcing information through the sense of touch (www.lpride.org). Based upon this notion we may conclude that LMS can be a rewarding learning experience.

Secondly, the students' attitude towards LMS remains significant. Students who believed that it was appropriate to 
use e-learning, are most likely to use them. This finding implies that e-learning use can motivate students' attitudes towards engaging in e-learning. Thus, efforts to enhance e-learning should be directed at changing attitudes of students. Academics and leading stakeholders are therefore asked to consider tuning in their pedagogy to highlight the benefits associated with e-learning. Since students are guided by the consequences of their actions, efforts should be made to influence their attitudes by focusing on natural consequences of e-learning. In particular, the awareness of e-learning leading to learning from best practices and, incentives from governmental agencies, may bring further change in students' attitude. Once students are educated on the impact of e-learning, they may change their attitude, from existing useful component to self-efficacy or perceived enjoyment and may begin to appreciate it and use e-learning management system more productively.

E-learning attitudes explain a greater variation in their intention to use, as opposed to other two variables especially the students' learning style. This finding supports the studies done by Taylor \& Todd, (1995); Ramayah et al. (2004); Wong (2012) and Brumini et al. (2014). However, the regression analysis confirms that e-learning attitudes have positive and significant relationship to students' intention to use e-learning in near future. Additional support for the strength of attitudes towards students' intention appears in the regression analysis with high t-value than the learning style. The implication of this finding is that efforts to bring a radical change in promoting e-learning would be predicted both by students' attitude and by focusing on the student learning style. However, the high value of attitude would further reinforce the implementation process. The non-significance of attitude towards educational technologies might be due to the general, not specific, questions that were asked about the students' attitudes towards educational technologies.

\section{Conclusion}

The study addresses the objectives: 1) to find out the most common learning style of the respondents and 2) to find out the relationship between students' learning style, their attitudes and their acceptance of e-LMS in near future. Firstly, the study used the VARK questionnaire to measure the learning style of 120 undergraduate students of both computing and business faculties. Result of study shows that beside the attitude, the majority (28\%) of the students follow single mode learning style-Kinesthetic (Doing) followed by multimode (20\%) (Reading + Doing). This further suggests that pedagogical instructional design considering the students' learning style and their positive attitude towards the usefulness of e-learning system, if implemented, would become successful. The institution may capitalize on these findings in order to create a competitive advantage as a leader and promoter of e-learning.

Future studies should be conducted that would allow participation of the whole institution to broaden the perspective in relation to understanding the students' learning style to adopt e-learning

\section{Significance for Practice and Recommendations}

The study has practical significance as it provides useful information for the educational leaders dealing with the daunting task of implementing e-LMS in institution of higher learning. By understanding the learning style of the learners the e-LMS "Ask-n-Learn" can be modified for easy implementation. Howles (2007) has suggested the following guidelines and are useful for practical applications in the context of higher education:

- To select instructional methods and media that matches the nature of the content to be taught. Use of demonstrating videos/graphics for content material, hands-on that are not only visual in nature but provide sufficient practice time and activities to muster the concept.

- To supplement the learner styles paradigm with other learner attributes that have been tried, tested and proven true such as prior knowledge, motivation, aptitude, and learner confidence related to task.

- To apply the holistic-analytic learning style model judiciously. There must be a balance in between application of learning style as over-designing for one particular 'style' may degrade learning for others.

\section{Acknowledgements}

The authors are thankful for the support of Dr. Florina Estrada of Quality Assurance Office, Institute of Technology Brunei.

\section{References}

Adewole-Odeshi, E. A. (2014). Attitude of Students towards e-Learning in South-West Nigerian Universities: An 
Application of TAM. Library, Philosophy and Practice (e-Journal), paper 1035.

Al-Doub, E., Goodwin, R., \& Al-Hunaiyyan, A. (2008). Students' Attitudes toward E-Learning in Kuwait's Higher Education Institutions. Retrieved Jan $10^{\text {th }}, 2015$ from www.apsce.net/icce2008/contents/proceeding_0841.pdf

Al-Khashab, H. M. (2007). Attitudes towards E-Learning: An Empirical Study in Kuwait, unpublished MBA thesis, Maastricht School of Management, Maastricht, The Netherland. Retrieved Jan $15^{\text {th }}$, 2010 from www.scribd.com/doc/2931290/Attitude-toward-Elearning

Allert, J. (2004). Learning Style and Factor Contributing to Success in an Introductory Computer Science Course. ICALT, 2004, 385-389. http://dx.doi.org/10.1109/icalt.2004.1357442

Ayesha, N., Raneem, O. S., Quadri, M. S. A., \& Al-Hamdan, N. (2011). Learning Style Preferences of Medical Students: A Single Institution Experience from Saudi Arabia. International Journal of Medical Education, 2, 70-73. http://dx.doi.org/10.5116/ijme.4e36.d31c

Bajraktarevic, N., Hall, W., \& Fullick, P. (2003). Incorporating learning styles in hypermedia environment: empirical evaluation. In Proceedings of Workshop on Adaptive Hyper Media and Adaptive Web-based Systems, 41-52.

Bart, M. (2009). Do Learning Style Matter? Retrieved from www.facultyfocus.com/articles/learning-style/document

Bassey, U., Umoren, G., Akuegwu, B., Udida, L., Ntukiden, P., \& Ekabua, O. (2007). Nigerian graduating students' access to e-learning technology: implications for higher education management. Proceedings of the $6^{\text {th }}$ international Internet Education Conference (ICT-Lean2007), Cairo, Egypt $2^{\text {nd }}-4^{\text {th }}$ September.

Bertea, P. (2009). Measuring Students'Attitude towards E-Learning: A Case Study. Proceedings of $5^{\text {th }}$ International Scientific Conference on eLearning and Software for Education, Bucharest, April $9^{\text {th }}-10^{\text {th }}$.

Brown, T., \& Zoghi, M., et al. (2009). Are Learning Style Preferences of Health Science Students Predictive of their Attitudes towards E-Learning? Australasian Journal of Educational Technology, 25(4), 524-543.

Brumini, G., Spalj, S., Mavrinac, M., Biocina-Lukenda, D., Strujic, M., \& Brumini, M. (2014). Attitudes towards e-learning amongst Dental Students at the Universities in Croatia. European Journal of Dental Education, 18(1), 15-23. http://dx.doi.org/10.1111/eje.12068

Brunei Darussalam Statistical Yearbook. (2012). Statistic Review Economy, Economy Planning Unit, Ministry of Finance: Brunei.

Brusilovsky, P., \& Millan. E. (2007). User Models for Adaptive Hypermedia and Adaptive Educational Systems. The Adaptive Web: Methods and Strategies of Web Personalization Lecture Notes Computer Science (LNCS), 4321, 3-53. http://dx.doi.org/10.1007/978-3-540-72079-9_1

Buzzetto-More, N. A. (2008). Student Perceptions of various E-Learning Components. Interdisciplinary Journal of E-Learning and Learning Objects, 4, 113-135.

Campbell, V., \& Johnstone, M. (2010). The Significance of Learning Style with respect to Achievement in First Year Programming Students. Proceedings of Australian Software Engineering Conference (ASWEC2010), Auckland, New Zealand. http://dx.doi.org/10.1109/aswec.2010.33

Carver, C. A., Howard, R. A., \& Lane, W. D. (1999). Addressing Different Learning Styles through Course Hyper media. IEEE Transactions on Education, 42(1), 33-38. http://dx.doi.org/10.1109/13.746332

Cheng, K. (2006). A Research Study on Students' Level of Acceptance in Applying E-learning for Business Course: A Case Study on a Technical College in Taiwan. Journal of American Academy of Business, 8(2), 265-272.

Cheng, G., \& Wong, T. (2014). A Study on Learning Styles and Acceptance of Using Second Life for Learning in a Visual Arts Course. Open Journal of Social Sciences, 2, 22-28. http://dx.doi.org/10.4236/jss.2014.22004

Churchill, G.A.J. (1979). A Paradigm for Developing Better Measures of Marketing Constructs. Journal of Marketing Research, XV(Feb), 64-73. http://dx.doi.org/10.2307/3150876

Coffield, F., Moseley, D., Hall, E., \& Ecclestone, K. (2004). Learning Styles and Pedagogy in Post-16 Learning: A Systematic and Critical Review. London: Learning and Skill Research Center.

Conlan, O., \& Wade, V. (2004). Evaluation of APeLs_ an Adaptive eLearning Service based on the Multi-model, Metadata-driven Approach. In T. Kanade et al. (series Eds), P. De Bra \& W. Nejdi (Vol. Eds), Lecture Notes in Computer Science: Vol. 3137. Proceedings of $3^{\text {rd }}$ international conference on adaptive hypermedia and adaptive Web-based system, 291-295. New York: Springer-Verlag. http://dx.doi.org/10.1007/978-3-540-27780-4_35 
Cronbach, L .J. (1951). Coefficient Alpha and the Internal Structure of Test. Psychometrika, 16, 297-334. http://dx.doi.org/10.1007/BF02310555

Davis, F. D. (1989). Perceived Usefulness, Perceived Ease of Use and User Acceptance of Information Technology. MIS Quarterly, 13, 983-1003. http://dx.doi.org/10.2307/249008

Davis, F. D., Bagozzi, R. P., \& Warshaw, P R. (1989). User Acceptance of Computer Technology: A Comparison of Two Theoretical Model. Management Science, 35(8), 982-1003. http://dx.doi.org/10.1287/mnsc.35.8.982

De-Bra, P., Brusilovshy, P., \& Kobsa, P. (2002). SIGUE: Making Web courses adaptive. Proceedings of $2^{\text {nd }}$ international conference on Adaptive, Hypermedia and Adaptive Web-based System (AH2002). Malaga, Spain, 376-379.

Dewey, J. (1966). Democracy \& Education. NY: Free Press.

Downey, S., Wentling, R., Wentling, T., \& Wadworth, A. (2005). The Relationship between National Culture and the Usability of an E-learning System. Human Resource Development International, 8(1), 47-64. http://dx.doi.org/10.1080/1367886042000338245

Dunn, R., \& Griggs, S. (2003). Synthesis of the Dunn and Dunn learning styles model research: Who, what, when, where and so what-the Dunn and Dunn learning styles model and its theoretical cornerstone. NY: St. John's University.

Dunn, R., \& Dunn, K. (1978). Teaching Students through their Individual Learning Styles: A Practical Approach. NY: Reston Publishing Company.

Effken, J. A., \& Doyle, M. (2001). Interface design and cognitive style in learning: an instructional computer simulation. Computers in Nursing, 19, 164-171.

Felder, R. M., \& Silverman, L-K. (1988). Learning and Teaching Style in Engineering Education. Engineering Education, 78(7), 674-681.

Fishbein, M., \& Ajzen, I. (1975). Belief, Attitude and Behaviour: An Introduction to Theory and Research. Addison-Wesley: Reading, Mass.

Fleming, N.D. (2005). VARK: a guide to learning styles. Retrieved January $15^{\text {th }}$, 2015 from http://www.vark-learn.com/english/index.asp

Fleming, N. D., \& Mills, C. (1992). Helping Students Understand How They Learn. The Teaching Professor, 7(4). Madison, Wisconsin, USA: Magma Publications.

Gardner, H. (1993). Frames of Mind: The Theory of Multiple Intelligences. New York: Basic Books.

Grasha, A. F., \& Yangarber-Hicks, N. (2000). Integrating teaching styles and learning styles with instructional technology. College Teaching, 48, 2-10. http://dx.doi.org/10.1080/87567550009596080

Greenall, C., Bonner, P., Beattie, R., \& Moss, K. (2007). Learning Styles: Is What Students Say What They Do? Retrieved from http://www.bioscience.heacademy.ac.uk/events/sitc07/papers/p17greenall.pdf

Hair, J. F., Anderson, R. E., Tatham, R. L., \& Blake, W.C. (1998). Multivariate Data Analysis, (4 ${ }^{\text {th }}$ Ed.). Englewood Cliff, N.J: Prentice Hall.

Honey, P., \& Mumford, A. (1992). The Manual of Learning Style ( $3^{\text {rd }}$ Ed.). Maidenhead, Peter Honey.

Howles, L. (2007). Learning styles: How to apply the latest research to designing e-learning. The ELearning Guild's Online Forums, University of Wisconsin, session 202, 1-16.

Keefe, J. (1988). Profiling and Utilizing Learning Style. NASSP Learning Style Series.

Kolb, D. A. (1984). Experiential Learning: Experience as the Source of Learning and Development. New Jersey: Prentice-Hall.

Laroussi, M., \& Benahmed, M. (1998). Providing an Adaptive Learning through the Web Case of CAMELEON: Computer Aided MEdium for LEarning on Networks. Proceedings of CALISCE98, $4^{\text {th }}$ international conference on computer Aided Learning and Instruction in Science \& Engineering, Goteberg, Sweden, 411-416.

Loo, R. (1999). Confirmatory factor analysis of Kolb's learning style inventory LSI-1985. British Journal of Educational Psychology, 69, 213-219. http://dx.doi.org/10.1348/000709999157680

Lu, H-P., \& Chiou, M-J. (2010). The impact of individual differences on e-learning system satisfaction: A 
contingency approach. British Journal of Educational Technology, 41(2), 307-323. http://dx.doi.org/10.1111/j.1467-8535.2009.00937.x

Marsh, C. J. (2004). Becoming a teacher: Knowledge, skills and issues ( $3^{\text {rd }}$ Ed.). Sydney: Pearson Education.

Mathieson, K. (1991). Predicting user intentions: Comparing the technology acceptance model with the theory of planned behavior. Information Systems Research, 2(3), 173-191. http://dx.doi.org/10.1287/isre.2.3.173

Monochehr, M-N. (2006). The Influence of learning styles on learner's in e-learning environment: An empirical study. Computers in Higher Education Economics Review, 18, 10-14.

Montessori, M. (1914). Dr. Montessori's own handbook. NY: Schocken Books-1965 (original work published in 1914).

Myers, I., McCaulley, M., Quenk, N., \& Hammer, L. (1998). The MBTI Manual: A Guide to Development and Use of the Myers-Briggs Type Indicator. Consulting Psychologists Press.

Ndume, V., Tilya, F., \& Twaakyondo, H. (2008). Challenges of adaptive E-Learning at higher learning institutions: A case study in Tanzania. International Journal of Computing \& ICT, 2(1), 47-59.

Paris, P. G. (2004). E-Learning: A Study on Secondary Students' Attitudes towards Online Web-Assisted Learning. International Education Journal, 5(1), 98-112.

Peter, S.E., Bacon, E., \& Dastbaz, M. (2009). Learning styles, personalization and adaptable e-learning. In: Uhomoibhi, James, Ross, Margaret and Staples, Geoff, (eds.), Fourteenth International Conference on Software Process Improvement Research, Education and Training, INSPIRE 2009. The British Computer Society, Swindon, UK, pp. 77-87.

Piaget, J. (1973). To Understand is to Invent. New York: Grossman.

Ramayah, T., Noor, N., Nasurdin, A. M., \& Sin, Q. B. (2004). The relationship between belief, attitude, subjective norms, intentions and behavior towards infant food formula selection: The views of Malaysian mothers. Gadiah Mada-International Journal of Business, 6(37), 405-418.

Ramayah, T., \& Suki, M. N. (2006). Intention to use mobile PC among MBA students: Implication for technology integration in the learning curriculum. UNITAR-E-Journal, 1(2), 1-10.

Randall, D. M. (1989). Taking stock: Can the theory of reasoned action explain unethical conduct? Journal of Business Ethics, 8, 873-882. http://dx.doi.org/10.1007/BF00384531

Reid, J. (1987). The learning style preferences of ESL Students. TESOL Qty, 21(1), 87-111. http://dx.doi.org/10.2307/3586356

Safavi, A. A. (2008). Developing countries and E-Learning program development. Journal of Global IT Management, 11(3), 47-64. http://dx.doi.org/10.1080/1097198x.2008.10856473

Sampson, D., \& Karagiannidis. C. (2002). Personalized Learning: Educational Technologies and Standardization Perspective. Interactive Educational Multimedia, 4, 24-39.

Sanders, D. W., \& Morrison-Shetlar, A. I. (2001). Student Attitudes toward Web-Enhanced Instruction in an Introductory Biology Course. Journal of Research on Computing in Education, 33(3), 337-365.

Selim, H. M. (2005). Critical Success Factors for E-Learning Acceptance: Confirmatory Factor Models. Proceedings of E-Business and Organizations in $21^{\text {st }}$ Century, International Conference, College of IT, UAE University, Dubai, UAE, 225-235.

Selwyn, N. (1997). Students' Attitudes toward Computers: Validation of a Computer Attitude Scale for 16-19 Education. Computer Education, 28(1), 35-41. http://dx.doi.org/10.1016/S0360-1315(96)00035-8

Seyal A. H. (2010). An Application of Theory of Reasoned Action to Understand Students' intentions toward e-Learning: Evidence from Bruneian Higher Learning Institutions. Paper Presented in International Conference on Diffusion of ICTs in Academia: Learning in the Digital Age in Islamic Countries. Khartoum, Sudan, Oct $4^{\text {th }}-5^{\text {th }}$.

Skinner, B. F. (1974). About Behaviorism. NY: Knopf.

Spechts, M., \& Opperman, R. (1998). ACE-adaptive courseware environments. The New Review of Hypermedia and Multimedia, 4, 141-161. http://dx.doi.org/10.1080/13614569808914699

Taylor, S., \& Todd, P. A. (1995). Understanding Information Technology Usage: A Test of Competing Models. 
Information Systems Research, 6(2), 144-176. http://dx.doi.org/10.1287/isre.6.2.144

Too, S. W. (2009). Students' learning styles and their academic achievement for taxation course-a comparison study. In proc of $2^{\text {nd }}$ international conference of teaching \& learning (ICTL), Malaysia.

Urdan, T. A., \& Weggen, C. C. (2003). Corporate E-Learning: Exploring a New Frontier. WRHAMBRECHT + CO.

Vermunt, J. D. (1998). The Regulation of Constructive Learning Processes. British Journal of Educational Psychology, 68, 149-171. http://dx.doi.org/10.1111/j.2044-8279.1998.tb01281.x

Watson, J. B. (1930). Behaviorism. University of Chicago Press.

Wong, L. (2012). Student Attitudes toward E-Learning: The First Year Accounting Experience. Issues in Information Science and Information Technology, 9, 195-208.

Wolf, C. (2003). i-Weaver: Towards Learning Style-based e-Learning in Computer Science Education. Proceedings of the $5^{\text {th }}$ Australasian Computing Education Conference (ACE2003), 273-279.

Zhenhui, R. (2001). Matching teaching styles with learning styles in East Asian Context. The Internet TESL Journal, 7(7). Retrieved from http://iteslj.org

\section{Note}

Note 1. Understanding your Learning Style retrieved from www.ldpride.net on Feb 5th, 2015 